\title{
The Role of ICT Projects in Enterprises: Investments, Benefits and Evaluation
}

\author{
Khaled H. Alyoubi ${ }^{1}$ \\ Information Systems Department, Faculty of Computing and Information Technology \\ King Abdulaziz University, Jeddah, Saudi Arabia
}

\begin{abstract}
The enterprise's dependency on Information and Communication Technologies (ICT) resources is essential, which cover their several business and operational activities. Enhancing operational capabilities, advancing working environment, and improving employees skills are major benefits provided by modern ICT resources. The real pressure is on organizations to upgrade the ICT infrastructure with latest development to compete in the market. This research investigates the role of ICT projects in an organization from investment, benefits and evaluation perspectives. Based on the literature review, the conceptual framework proposed to understand the relationship between ICT project's investments, benefits, and evaluation. The main purpose of this study is to investigate the approach of enterprises toward ICT investments. Moreover, to understand the type of ICT evaluation strategies that practicing by organizations. Therefore, the proposed framework is applied and validated through multiple case studies to confirm the list of variables collected from literature review. The conducted investigation will help to certify the findings of literature review through selected case studies. The analysis of responses presented in different format to understand the current role and status of ICT projects; investment, benefits and evaluation performed in different organizations. The outcome of this study will addresses substantial factors and offers references for the organization to build their ICT investment and evaluation model. The type of ICT investment, benefits, and measurement models extracted in this research can act as a reference for the organization to develop their own ICT investments policies.
\end{abstract}

Keywords-ICT projects; ICT investment; ICT benefits; ICT evaluation strategies

\section{INTRODUCTION}

Information and Communication Technologies (ICT) resources are covering major part in executing organizational operational activities and in increasing business growth. According to the facts and figures the enterprises are investing large amount on implementing and enhancing ICT applications to take competitive advantage. The Gartner reported in January 2020 that overall global ICT spending will reach around \$3.9 Trillion in the end of this year [1]. This highlights the dependency, importance, and impact of ICT investments over enterprises. The ICT investment is reasonably increasing every year due to latest technological development and new business strategies. It is ultimately improving the business growth and reducing the human efforts, through automating the business processes [2].

The main purpose behind big ICT investments are many as discussed in previous studies. Supporting business architecture
[3], increase productivity [4], creating electronic services [5], digital marketing [6], enterprise and decision support systems [7] are some of the factors that require more investments from the organizations. The ICT investments has been categorized in different sectors such as devices, data center, enterprise systems as illustrated in Fig. 1. The list of sectors defined by Gartner, by mentioning the amount of investment for each category. It can be seen from the figure that out of five categories the maximum amount invested on "communication services", whereas the least amount is investing on "data services".

The ICT investments creates numerous benefits to the organizations. The list of benefits identified in literature has divided in two different types: (i) tangible benefits and (ii) intangible benefits [8]. Tangible benefits are those, which can be measured using quantitative strategies such as return on investment, cost and revenue ratio, return on assets and by using other financial formulae [9]. On the other side, intangible benefits are related to those factors, which cannot be measured using direct equation. Indeed, these factors are of qualitative nature that requires multiple questions to be answered during evaluation process. In one of the report, intangible benefits are also known as value on investment, illustrates as the number of values ICT investment generated in the organization [10], [11]. The list of benefits discussed in previous researches are known as data quality and decision making process [12], and communication skills [13].

The evaluation of ICT investment is a complex but essential procedure regularly applied in the organization. It can provide the status of ICT resources in the organization before and after implementation. There are different evaluation strategies proposed in earlier researches. The traditional approach is known as financial approach, which provide the direct benefits generated from the particular ICT application [14]. Other type of evaluation methodologies discussed by [15] are formative and summative approach. Recently, the value on investment is commonly used and applied by different organization. The idea behind this kind of evaluation is to measure the data quality generated by any ICT investment [16]. For measuring the benefits from value's perspective has been modified and applied various time [11], [17] as this provide the new way for measuring the ICT investments. Still the measurement process of ICT benefits evaluation is under progress due to its vast implications on organization can be categorized as financial and non-financial benefits. 


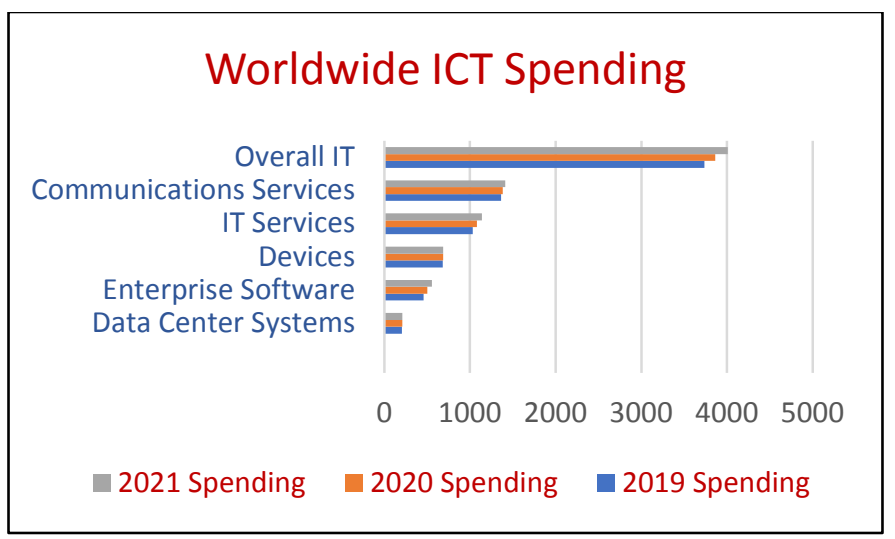

Fig. 1. Worldwide IT Spending Forecast (in Billions of U.S. Dollars) [1].

The main problem undertaken in this research is "What are the major ICT investments organizations are doing and in which sector? and how they evaluate those investment”? In addition, the study examined the most and least invested ICT sector in the organization. As companies are investing large amount on ICT but still there is complexity involves in evaluation approaches. A strategy that can evaluate the both; return and value generated from those investments [18]. Likewise, the problem sub-categorized in this study to observe the most common approaches organization are employing for measuring the benefits created by the particular ICT investment. The other supported questions that will be explored in case studies are risk involvement and prefer time of measurement such as pre or post.

The remaining paper has structured as follows. The next section explained the investment and evaluation status in previous studies. It will help to extract different questions to be asked in case studies during investigation. Section III discussed about the methodology applied in this study. In addition, the proposed framework is explained in that section. Section IV will talk about the implementation steps applied. It will also provide the detailed analysis on number of questions asked from different case studies. Finally, the last section will conclude this paper followed by proposing the future work.

\section{ICT PROJECTS: INVESTMENT AND EVALUATION}

The role of ICT in an organization is important to run different information systems. Apart from big investments on information technology (IT) infrastructure, utilization of those resources is the main concern of the organization [19]. To know the status of ICT resources organization used different type of evaluation strategies. Traditionally, financial approaches such return on investment and return on assets are commonly known for measuring the return from any investment [20]. Currently, the progression in evaluation techniques suggested different other methodologies such as non-financial approach [21], portfolio management approach [22], economic approach [23], balanced scorecard [24], and others.

The development in ICT evaluation strategies is progressed due to high integration of ICT resources in business communities. The increase of ICT resources in organizations created positive impact over developing new
ICT evaluation strategies. The use of ICT applications can be realized by reviewing the previous work presented in different countries. For example, ICT involvement in Spanish class room system for learning activities [25], ICT household resources evaluation in Polish [26], and assessment of ICT tools in Switzerland [27]. In addition, different researches presented to measure the ICT involvement in communities such as relationship between ICT and environment quality [28], ICT and health industry [29], ICT and productivity [30][32], ICT and teaching environment [33]-[35], last but not the least ICT dependency in building electronic services [5], [36].

The above paragraph highlights the major development in organizations are highly depending on ICT resources. Therefore, this study investigated the organization's point of view on measuring those investment. The summary of common evaluation strategies presented in Table I. The traditional financial approach does not provide the comprehensive report as it will just calculate the return from particular investment [9]. On the other side value on investment (VOI) is new addition in evaluation strategies, which can describe what type of values ICT resources provided to the industry. There is a progressive development in VOI based strategies presented in previous work such as moving from ROI to VOI [10], discussed the purpose and objectives of measuring non-financial factors. Those factors can be helpful for the organization that are public and nonprofitable, where they do not consider more about return on investment rather their major concern is how much value generated by the ICT resources.

TABLE I. ICT PROJECT EVALUATION APPROACHES

\begin{tabular}{|c|c|c|c|}
\hline Approach & $\begin{array}{l}\text { Major } \\
\text { Category }\end{array}$ & $\begin{array}{l}\text { Pre or Post } \\
\text { Evaluation }\end{array}$ & Methodology \\
\hline $\begin{array}{l}\text { Return on } \\
\text { Investment } \\
\text { [37] }\end{array}$ & $\begin{array}{l}\text { Financial } \\
\text { Approach }\end{array}$ & Post & $\begin{array}{l}\text { By calculating the ratio } \\
\text { between the investment and } \\
\text { generated returns. }\end{array}$ \\
\hline $\begin{array}{l}\text { Value on } \\
\text { Investment } \\
{[10]}\end{array}$ & $\begin{array}{l}\text { Non- } \\
\text { Financial } \\
\text { Approach }\end{array}$ & Post & $\begin{array}{l}\text { Generally, it uses different } \\
\text { dimensions for } \\
\text { measurement such as; } \\
\text { organizational impact, } \\
\text { community impact and } \\
\text { others. }\end{array}$ \\
\hline $\begin{array}{l}\text { Giga } \\
\text { Information } \\
\text { Framework } \\
\text { [38] }\end{array}$ & $\begin{array}{l}\text { Portfolio } \\
\text { Manageme } \\
\text { nt } \\
\text { Approach }\end{array}$ & Pre & $\begin{array}{l}\text { It's a project based } \\
\text { approach used by } \\
\text { decomposing the objectives } \\
\text { of the project and predict } \\
\text { the potential impact. }\end{array}$ \\
\hline VMM [39] & $\begin{array}{l}\text { Multi } \\
\text { Dimension } \\
\text { Approach }\end{array}$ & Pre & $\begin{array}{l}\text { Evaluating the potential } \\
\text { performance of the project } \\
\text { by adding multiple } \\
\text { dimensions and phases. }\end{array}$ \\
\hline $\begin{array}{l}\text { IDA-VOI } \\
\text { Approach } \\
\text { [11] }\end{array}$ & $\begin{array}{l}\text { Multi } \\
\text { Dimension } \\
\text { Approach }\end{array}$ & Pre and Post & $\begin{array}{l}\text { Depends on multiple } \\
\text { domain and dimensions like } \\
\text { cost-benefits analysis and } \\
\text { value analysis. }\end{array}$ \\
\hline $\begin{array}{l}\text { Information } \\
\text { Economics } \\
\text { [23] }\end{array}$ & $\begin{array}{l}\text { Integrated } \\
\text { Approach }\end{array}$ & Pre & $\begin{array}{l}\text { Integration of multiple } \\
\text { approached used in this } \\
\text { techniques such as ROI, } \\
\text { NPV. In addition also } \\
\text { combining dimensions for } \\
\text { measuring value on } \\
\text { investment. }\end{array}$ \\
\hline
\end{tabular}


The ICT investment are generating numerous benefits need to be evaluated using proper technique. According to [40] the ICT values are directly related with the main objective of ICT investment. For example, if the organization implemented new strategy for data integration and backup system, the benefit from this project will be known as "informational benefits". Whereas, these benefits cannot be assessed using ROI formula. It will require different type of questions to be examined properly. Meanwhile, there are different issues highlighted by the scholars while measuring these type of benefits. For example, due to their implications, there is no direct formula for evaluating the list of informational benefits [41]. Therefore, this research took a small step towards proposing a framework for measuring different types of investment as discussed in following section.

\section{METHODOLOGY}

The research methodology is a procedure to develop detailed and step-wise approach for attaining the answers of problems discussed in this study [42]. Therefore, the research framework as shown in Fig. 2 illustrating the overall approach taken in this study to discover the solution for the research questions. As evident from the figure the research considered the case study strategy in this study for data gathering. This type of approach is commonly used, which provides the latest experiences of the major stakeholders in the case studies [43]. Moreover, the case study is appropriate in this kind of research, where detailed analysis and company's procedures are investigated on behalf of research question [44]. The case study approach is commonly used in previous researches, specifically in the field of ICT investment and evaluation [45]-[47].
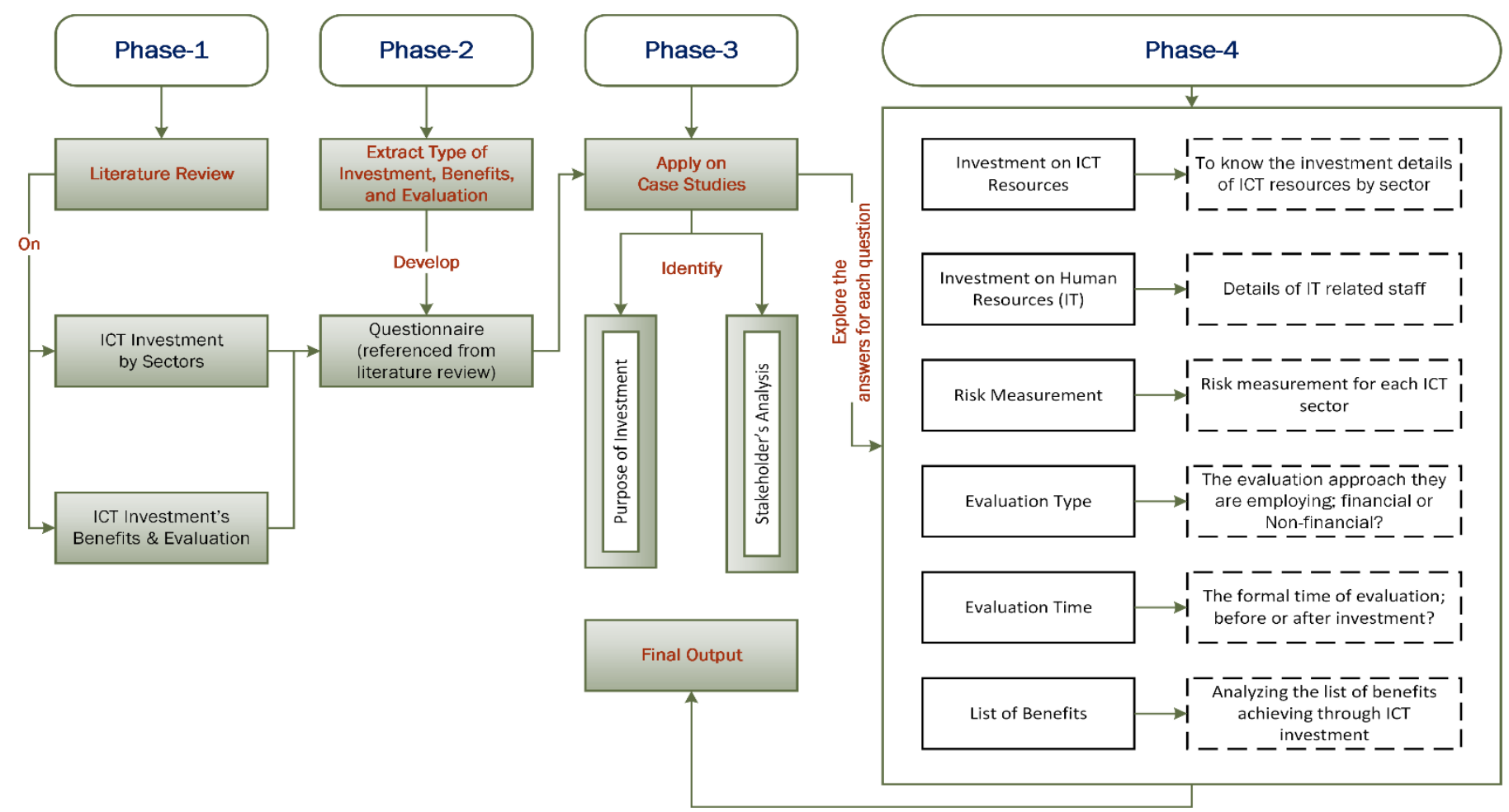

Fig. 2. A Framework for Analyzing the Role of ICT Projects in Enterprise.
Therefore, based on the findings from literature review the list of questions have been extracted. The questions asked from each case study for inquiring about their approach on ICT investment, benefits, and assessment procedures. According to the Fig. 1, the first two phases has covered with the help of literature review. The questionnaire developed with the help of previous work, therefore, each question is properly referenced to the original work as mentioned in the next section. The purpose of referencing the questions from literature review, is to validate the construct developed in this study, which has been presented earlier from different scholars. Another main idea was to integrate multiple theories presented by different scholars in one framework.

The next phase in the model is the selection of case studies and inquire about basic idea of ICT project investment; known as Phase-3. The first question investigates in this phase is to understand the objectives behind each investment. To identify the purpose of investment is much associated with getting the idea of potential impact of ICT resources. Secondly, stakeholder's analysis will be performed to estimate the list of beneficiaries. Both of these questions are asked prior to major investigation as this phase will provide the basic information about the ICT applications and investment. The idea of inquiring about ICT project's objectives and stakeholder's analysis is presented and validated in previous researches [8], [48]. ICT applications facilitates different kind of stakeholders, this step will help in investigating the further research questions. The purpose of investment will also identify the number of services it will provide and who will receive those benefits. This phase will lead us towards the final phase of this model that is Phase-4.

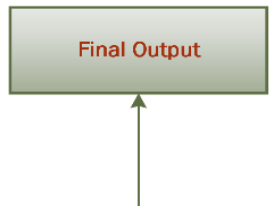


Finally, the last step in the framework is about to investigate the main research problem, described in this study. There are number of questions asked as extracted form literature review. The first two questions are related to gather the information about the type of investment. It will further provide the details, whether the amount invested for implementing ICT resources or hiring IT staff. The technical resources can be data center or ICT infrastructure, and IT human resources such as technical staff or IT consultants. Furthermore, the third question is about to assess risk involvement in those investment, and what is the level of risk. The next two queries are related with evaluation type and time. Some organizations are only interested in financial return, while others can consider qualitative assessment tool as well. Evaluation before project initiation or after implementation is another research question asked in this study. The last question illustrating in the framework is about number of benefits achieved from the ICT investment. For more clear understanding, the questions related to assessment approaches were asked to evaluate the latest ICT project implemented in the case studies. From the implementation steps it can be understand that the main reason and purpose of this study in analyzing the ICT project impacts and benefit on selected case studies.

\section{IMPLEMENTATION, RESULTS AND DISCUSSION}

As discussed in the previous section, the proposed framework is divided in multiple stages. The first two phases was already executed by reviewing vast literature review. During the review process, there are multiple finding discovered as follows. The ICT investment are normally divided into two categories; (i) technical investments and (ii) human resource (IT) investments [49]. The findings suggests that both types of investments can be evaluated using same strategy. As the evaluation process start by investigating number of objectives and list of beneficiaries. The identification of both can help us to apply the pre or post evaluation smoothly. The research identify the motivation behind each ICT investment executed in case studies. The implementation steps mentioned in Fig. 2 applied in sequence on each study. The generated results from each step are discussed in following sub-sections.

\section{A. Case Studies - Overview}

Data collected from literature review further applied, validated, and refined through case studies. As this research used qualitative approach, in which single source of data cannot provide the detailed analysis [44]. Furthermore, as described by [50] that validation of construct using single case study does not provide sufficient results if responses collected from same organization. However, the idea of selecting more than one case study is encouraged several time due to repeating the same question and justify the results several time by asking from multiple organization [51], [52]. Therefore, the framework validation applied on five case studies located in Pakistan.

Based on the data extracted from literature review, the structured questions was designed and sent to the organizations. The same questionnaires were sent to each case study for clear understanding and analysis on collected responses. The collected sample size (65) was feasible as required sample size in case study research [53]. Table II explains the details of each case study, where due to privacy issues, the company's names were kept confidential. The table is illustrating the characteristics of collected data from each organization.

TABLE II. SElected CASE StUdies Characteristics

\begin{tabular}{|l|l|l|l|}
\hline Organization & $\begin{array}{l}\text { Employee } \leq 3 \\
\text { Years' of IT } \\
\text { Experience }\end{array}$ & $\begin{array}{l}\text { Employee > 3 } \\
\text { Years' of IT } \\
\text { Experience }\end{array}$ & $\begin{array}{l}\text { Total } \\
\text { Participants }\end{array}$ \\
\hline Educational Institute & 4 & 16 & 20 \\
\hline Bank & 2 & 8 & 10 \\
\hline Hotel & 7 & 8 & 15 \\
\hline Restaurant & 5 & 7 & 12 \\
\hline $\begin{array}{l}\text { Manufacturing } \\
\text { Industry }\end{array}$ & 3 & 5 & 8 \\
\hline
\end{tabular}

Table II representing the total number of participants selected in this case study. As this research does not sent the questionnaire to anyone, but the participant's selection were based on their involvement with ICT project investment and evaluation. Therefore, the ICT users were not part of this study, but only middle and higher management employees were asked to participate in the research. The data showing in above table highlighting the average experience of the respondent is higher than three years. It indicates the validity of the responses is reflecting through their experience. Moreover, the maximum participants belong to "educational institute”, also it was the biggest organization in this survey.

\section{B. ICT Projects - Sector Wise Investment}

The first thing that examined by the case studies is to understand their sector wise ICT investment. Basically, this question is referring to the published report by Gartner, where they provided the worldwide ICT investment in different sectors [1]. Originally there are five categories, but for making it clear we converted into three main categories as shown in Table III. The table is representing the yearly investment in all categories. The data suggests that maximum investment are for the enhancement of ICT infrastructure. The collected data is validated through Gartner report also that the communication infrastructure is the largest invested sector as shown in Fig. 1. According to the collected data, out of the three categories mentioned in the table, "software" is the lowest investment sector. It can have different reasons: (i) software is one time installment, and most of the time they run for many year with some updates, (ii) some organizations outsource their main software, and (iii) software consist of few requirements than ICT infrastructure and electronic services. Overall, findings suggests the three major categories are very common in the organizations, where they are investing enough amount.

\section{Investment on Human Resources (IT)}

The next investigation performed using a similar question but for investment on human resources. Scholars have discussed this type of investments in previous researches, where they suggested that IT consultant, IT staff, and user training are part of ICT project's implementation [18], [54]. Therefore, this question is referred to those researches, and we 
asked the status of investment in case studies. The purpose is to estimate overall status of ICT project's investment. The responses were collected in the form of qualitative approach, where three options were provided for each category as mentioned in Table IV. As showing in the table, IT staff are playing major role in the organization and it seems the hiring is not happened frequently. It shows that the experience is important, and organizations are willing to be consistent with the experienced employees and do not want to replace them. The table is representing that consultants services are commonly taken in the case studies for ICT projects. Commonly, they are responsible for the whole project starting from the idea till the project implementation. Some organizations also hire them for post evaluation and auditing services. In addition, some enterprises are interested to conduct training workshop often. The table suggested that most of them are hiring trainers to train their employees for new systems.

TABLE III. ICT PRojects - Sector Wise InVESTMENT (PERCENTAge)

\begin{tabular}{|l|l|l|l|}
\hline Organization & Software & $\begin{array}{l}\text { ICT } \\
\text { Infrastructure }\end{array}$ & $\begin{array}{l}\text { Electronic } \\
\text { Services }\end{array}$ \\
\hline Educational Institute & $30 \%$ & $40 \%$ & $30 \%$ \\
\hline Bank & $20 \%$ & $30 \%$ & $50 \%$ \\
\hline Hotel & $20 \%$ & $30 \%$ & $50 \%$ \\
\hline Restaurant & $20 \%$ & $40 \%$ & $40 \%$ \\
\hline $\begin{array}{l}\text { Manufacturing } \\
\text { Industry }\end{array}$ & $30 \%$ & $60 \%$ & $10 \%$ \\
\hline
\end{tabular}

TABLE IV. INVESTMENT ON HUMAN RESOURCES (IT)

\begin{tabular}{|l|l|l|l|}
\hline Organization & IT Staff & Consultancy & Trainer \\
\hline Educational Institute & Frequently & Sometime & Frequently \\
\hline Bank & Sometime & Rarely & Frequently \\
\hline Hotel & Sometime & Frequently & Rarely \\
\hline Restaurant & Rarely & Frequently & Sometime \\
\hline Manufacturing Industry & Sometime & Frequently & Frequently \\
\hline
\end{tabular}

\section{ICT Projects - Risk Measurement}

The risk involves in every project as with ICT project. Most of the time risk assessment are measured using percentage or by using values between "low" and "high", whereas based on the situation the values of risk are modified. The chances of risks are telling also the size of damage after occurring of any bad event. There are many researches that have discussed about risk management in ICT projects [9], [55]. Accordingly, in this study we inquire about organization's point of view about risk involvement under each ICT sector and the chances of damages as shown in Table V. To make it clear the study asked about the three categorized ICT sector. Based on the collected data, it can be clearly seen that "electronic services" are on high risk in all organizations except "Manufacturing Industry". The "electronic services" are directly connected with the internet and may have vulnerability as dealing with customers using online environment. Hacker's attack on online services is the challenging threat for the organization. Whereas the "manufacturing industry" has provided few online services, therefore, they have low risk involvement there, but "very high" for "software" and "ICT infrastructure" as there major work related with these two categories. As per the analysis, low risk means, the organization has backup for those resources or not fully dependent on it. However, the very high, high and low risks refer to the chances as well as the size of damage, if any bad event happened with those resources.

TABLE V. ICT PROJECTS - RISK MEASUREMENT

\begin{tabular}{|l|l|l|l|}
\hline Organization & Software & $\begin{array}{l}\text { ICT } \\
\text { Infrastructure }\end{array}$ & $\begin{array}{l}\text { Electronic } \\
\text { Services }\end{array}$ \\
\hline $\begin{array}{l}\text { Educational } \\
\text { Institute }\end{array}$ & Low & High & Very High \\
\hline Bank & High & High & Very High \\
\hline Hotel & Low & Very High & Very High \\
\hline Restaurant & Low & Very High & Very High \\
\hline $\begin{array}{l}\text { Manufacturing } \\
\text { Industry }\end{array}$ & Very High & Very High & Low \\
\hline
\end{tabular}

\section{E. ICT Projects - Evaluation Type}

The next phase of this study is to explore the enterprise's approach towards evaluation of ICT project. For this, we have provided the major categories of ICT evaluation approaches to the participants to know what they are practicing commonly. The main reference to this question are [9], [56] where researchers provided different types of categories for assessing the ICT investment. Although, the time of evaluation also play a major role in measuring the impact of ICT resources that has discussed in next section. The selected common ICT project evaluation approaches with the responses are shown in Table VI. The question arose in front of respondents by asking their opinion about what they are practicing. The financial approach used to calculate the return from any investment. Most common approach used by all is "ROI". Same is not the case with non-financial approaches, some of them used "VOI" based approach for some projects but not very common. Normally, VOI based approach are useful to know about how much value the users or customers received from any ICT project. The example of values are discussed by [13] in the form of organizational values generated by ICT resources. Finally, some organization also apply strategy based approach for evaluation, such as portfolio management. Hiring of consultant agency for assessment is the next option asked in this study, which is not very common strategy in the case studies.

TABLE VI. ICT PROJECTS - EVALUATION TYPE

\begin{tabular}{|l|l|l|l|l|}
\hline Organization & $\begin{array}{l}\text { Financial } \\
\text { Model }\end{array}$ & $\begin{array}{l}\text { Non-Financial } \\
\text { Model }\end{array}$ & $\begin{array}{l}\text { Strategic } \\
\text { Approach }\end{array}$ & $\begin{array}{l}\text { Consultant } \\
\text { Agency }\end{array}$ \\
\hline $\begin{array}{l}\text { Educational } \\
\text { Institute }\end{array}$ & ROI & VOI & No & $\begin{array}{l}\text { Based on } \\
\text { Project }\end{array}$ \\
\hline Bank & ROI & $\begin{array}{l}\text { Based on } \\
\text { Project }\end{array}$ & Sometime & Yes \\
\hline Hotel & ROI & $\begin{array}{l}\text { Based on } \\
\text { Project }\end{array}$ & Sometime & No \\
\hline Restaurant & ROI & $\begin{array}{l}\text { Based on } \\
\text { Project }\end{array}$ & No & No \\
\hline $\begin{array}{l}\text { Manufacturing } \\
\text { Industry }\end{array}$ & ROI & VOI & No & Yes \\
\hline $\begin{array}{l}\text { *ROI: Return on Investment } \\
\text { *VOI: Value on Investment }\end{array}$ & \multicolumn{5}{|l}{} \\
\hline
\end{tabular}




\section{F. ICT Projects - Evaluation Time}

This section is directly associated with the previous section, where the time of approach explored. ICT project evaluation strategies are commonly divide in two categories; pre-evaluation and post-evaluation. Mainly, the question is extracted and referenced from the work applied by [57] where they categorized the evaluation strategies into four different types as mentioned in Table VII. According to the collected data, it is evident that all organization are curious about measuring the ICT investment using any approach. Therefore, the following table is showing the acceptance from all cases and highlighting the positive use of evaluation strategy. Most of the respondents agreed that there is a proper mechanism for evaluating the ICT project. Sometime, they do it before implementing it and sometime after. The project based evaluation is also a popular way in case studies, where impact of project evaluated after its execution. It is more direct approach when the implications of ICT resource can be measured based on the project's objectives. Finally, most of the organization practicing ICT evaluation on yearly bases as well. This type of evaluation is not related with particular project, rather it provides the comprehensive analysis on a performance of ICT resources in a complete lunar year.

\section{G. ICT Projects - List of Benefits}

Finally, the last questions asked in this study was related to number of benefits ICT project can generate. The question is referred to the study where they identify different type of benefits such as tangible benefits and intangible benefits [58]. Therefore, we select a mixed list of benefits extracted from [58] and asked from the case studies to find out their consent on each, if they agreed or not as illustrated in Table VIII. The purpose was to identify if case studies are supporting the variable and consider those variables as one of the benefits of ICT project or not. Regarding, "information quality" and "assets security" got full confidence from all case studies as the performance of these resources can be enhanced by ICT project. The remaining two variables, "employee skills" and "customer satisfaction" received partial agreement from case studies. Both of these benefits are kind of intangible benefits, which can have conflict of agreement. In previous studies, all of these benefits have been discussed and validated through number of items [40], [59] and confirmed as ICT benefits. The results presented in this section provide the comprehensive analysis on collected data, purely based on participant's responses from case studies. The list of benefits selected in this study were four, but it can be many, which can be identified based on the objectives of ICT project.

TABLE VII. ICT PROJECTS - EVALUATION TIME

\begin{tabular}{|l|l|l|l|l|}
\hline Organization & $\begin{array}{l}\text { Pre- } \\
\text { Evaluation }\end{array}$ & $\begin{array}{l}\text { Post- } \\
\text { Evaluation }\end{array}$ & $\begin{array}{l}\text { Project } \\
\text { Based }\end{array}$ & $\begin{array}{l}\text { Yearly } \\
\text { Bases }\end{array}$ \\
\hline $\begin{array}{l}\text { Educational } \\
\text { Institute }\end{array}$ & Yes & Sometime & Yes & Sometime \\
\hline Bank & Yes & Yes & Yes & Yes \\
\hline Hotel & Yes & Yes & Yes & Yes \\
\hline Restaurant & Yes & Yes & Yes & Yes \\
\hline $\begin{array}{l}\text { Manufacturing } \\
\text { Industry }\end{array}$ & Yes & Sometime & No & Yes \\
\hline
\end{tabular}

TABLE VIII. ICT PROJECTS - LIST OF BENEFITS

\begin{tabular}{|c|c|c|c|c|}
\hline Organization & $\begin{array}{l}\text { Information } \\
\text { Quality }\end{array}$ & $\begin{array}{l}\text { Assets } \\
\text { Security } \\
\end{array}$ & $\begin{array}{l}\text { Employee } \\
\text { Skills } \\
\end{array}$ & $\begin{array}{l}\text { Customer } \\
\text { Satisfaction }\end{array}$ \\
\hline $\begin{array}{l}\text { Educational } \\
\text { Institute }\end{array}$ & $\sqrt{ }$ & $\sqrt{ }$ & $\mathrm{X}$ & $\sqrt{ }$ \\
\hline Bank & $\sqrt{ }$ & $\sqrt{ }$ & $\mathrm{X}$ & $\sqrt{ }$ \\
\hline Hotel & $\sqrt{ }$ & $\sqrt{ }$ & $\sqrt{ }$ & $\sqrt{ }$ \\
\hline Restaurant & $\sqrt{ }$ & $\sqrt{ }$ & $\sqrt{ }$ & $\mathrm{X}$ \\
\hline $\begin{array}{l}\text { Manufacturing } \\
\text { Industry }\end{array}$ & $\sqrt{ }$ & $\sqrt{ }$ & $\sqrt{ }$ & $\mathrm{X}$ \\
\hline
\end{tabular}

\section{CONCLUSION}

ICT project are playing major role in organizational development and business growth. The study presented the idea of examine the current status and practice enterprises are doing for ICT project's investment, evaluation, and benefits. The list of questions are extracted from related work, which further validated through multiple case studies. Therefore, the variable collected from related work has confirmed by selected case studies. The results indicated that organizations are doing most of the investment on building ICT infrastructure. Whereas electronic services considered on high risk zone. Return on investment selected as foremost evaluation strategy for all organization. Apart from using any strategy, but organization are willing to do evaluation before and after implementation to assess the impact and return value from ICT project. Finally, all organizations are agreed on the argument that ICT project creates positive impact on organizations.

In future, the result can be refined by implementing the framework on different case studies selected from multiple regions. This area of research still requires some quantitative measuring framework to understand the visible impact of ICT projects on organizations.

\section{REFERENCES}

[1] STAMFORD, "Gartner Says Global IT Spending to Reach \$3.9 Trillion in 2020,” 2020.

[2] L. Juhaňák, J. Zounek, K. Záleská, O. Bárta, and K. Vlčková, "The relationship between the age at first computer use and students' perceived competence and autonomy in ICT usage: A mediation analysis," Comput. Educ., vol. 141, no. June, 2019.

[3] A. A. Al-ghamdi and F. Saleem, "The Impact of ICT Applications in the Development of Business Architecture of Enterprises," Int. J. Manag. Stud. Res., vol. 4, no. 4, pp. 22-28, 2016.

[4] M. Kante, R. Oboko, and C. Chepken, "An ICT model for increased adoption of farm input information in developing countries: A case in Sikasso, Mali,” Inf. Process. Agric., vol. 6, no. 1, pp. 26-46, 2019.

[5] M. K. Anser, Z. Yousaf, M. Usman, and S. Yousaf, "Towards strategic business performance of the hospitality sector: Nexus of ICT, emarketing and organizational readiness,” Sustain., vol. 12, no. 4, pp. 117, 2020.

[6] J. M. Millán, S. Lyalkov, A. Burke, A. Millán, and A. van Stel, “'Digital divide' among European entrepreneurs: Which types benefit most from ICT implementation?,” J. Bus. Res., no. December 2018, pp. 1-15, 2019.

[7] F. Saleem and A. S. Al-Malaise, "Implementation of Data Mining Approach for Building Automated Decision Support Systems," in Information Society (i-Society), International Conference on (pp. 127130). IEEE., 2012, pp. 127-130. 
[8] F. Saleem, N. Salim, A. G. Fayoumi, and A. Alghamdi, A General Framework for Measuring Information and Communication Technology Investment: Case Study of Kingdom of Saudi Arabia, vol. 322. 2012.

[9] L. Dadayan, "Measuring return on government IT investments," in Proceedings of the 13th European Conference on Information Technology Evaluation, 2006, no. September, p. 12.

[10] D. Hurley, "Changing the View of ROI to VOI—Value on Investment," 2001.

[11] IDA-VOI, “IDA Value Of Investment," 2003.

[12] S. Gregor, M. Martin, W. Fernandez, S. Stern, and M. Vitale, "The transformational dimension in the realization of business value from information technology,” J. Strateg. Inf. Syst., vol. 15, no. 3, pp. 249270, 2006.

[13] S. Shang and P. B. Seddon, "Assessing and managing the benefits of enterprise systems: the business manager's perspective," Inf. Syst. J., vol. 2000, pp. 271-299, 2002.

[14] C. A. Magni, "Internal Average Rate of Return and Aggregate Return on Investment," Invest. Decis. Log. Valuation, Springer, pp. 555-611, 2020.

[15] M. Hersh, "Evaluation framework for ICT-based learning technologies for disabled people," Comput. Educ., vol. 78, pp. 30-47, 2014.

[16] B. Heinrich, M. Klier, A. Schiller, and G. Wagner, "Assessing data quality - A probability-based metric for semantic consistency,” Decis. Support Syst., vol. 110, no. April, pp. 95-106, 2018.

[17] E. Jed, J. Wachowicz, and S. Chun, "Social Return on Investment:Exploring Aspects of Value Creation in the Nonprofit Sector,” 2000.

[18] M. Carcary, "ICT Evaluation in the Irish Higher Education Sector," Electron. J. Inf. Syst. Eval., vol. 12, no. 2, pp. 129-140, 2009.

[19] E. Rodríguez-Crespo and I. Martínez-Zarzoso, "The effect of ICT on trade: Does product complexity matter?,” Telemat. Informatics, vol. 41, no. April, pp. 182-196, 2019.

[20] W. Van Grembergen and S. De Haes, "Measuring and demonstrating the value of IT,” IL 60008 USA, 2005.

[21] Z. Irani, J.-N. Ezingeard, and R. J. Grieve, "Costing the true costs of IT/IS investments in manufacturing: a focus during management decision making,” Logist. Inf. Manag., vol. 11, no. 1, pp. 38-43, 1998.

[22] M. Kozina and D. Popović, "VAL IT Framework and ICT benefits," in European Conference on Information and Intelligent Systems, 2010, pp. 221-227.

[23] M. Parker and R. Benson, "Information Economics," Inf. Econ., no. C, pp. 1-15, 1989.

[24] R. Kaplan and D. Norton, "Using the balanced scorecard as a strategic management system,” Harv. Bus. Rev., pp. 75-85, 1996.

[25] M. Arrosagaray, M. González-Peiteado, M. Pino-Juste, and B. Rodríguez-López, "A comparative study of Spanish adult students' attitudes to ICT in classroom, blended and distance language learning modes,” Comput. Educ., vol. 134, no. October 2018, pp. 31-40, 2019.

[26] A. Karczmarczyk, J. Wątróbski, J. Jankowski, and E. Ziemba, "Comparative study of ICT and SIS measurement in Polish households using a MCDA-based approach,” in Procedia Computer Science, 2019, pp. 2616-2628.

[27] J. C. K. H. Riedel and M. Vodicka, Evaluating the Melodie ICT tool for supporting idea generation, vol. 43, no. 17. IFAC, 2010.

[28] D. Avom, H. Nkengfack, H. K. Fotio, and A. Totouom, "ICT and environmental quality in Sub-Saharan Africa: Effects and transmission channels," Technol. Forecast. Soc. Change, vol. 155, no. March, p. 120028, 2020.

[29] U. P. Dutta, H. Gupta, and P. P. Sengupta, "ICT and health outcome nexus in 30 selected Asian countries: Fresh evidence from panel data analysis,” Technol. Soc., vol. 59, no. July, p. 101184, 2019.

[30] N. Abramova and N. Grishchenko, "ScienceDirect ScienceDirect ICTs, Labour Labour Productivity Productivity and and Employment: Employment : Sustainability Sustainability in in Industries Industries in in Russia,” Procedia Manuf., vol. 43, pp. 299-305, 2020.
[31] P. Koutroumpis, A. Leiponen, and L. D. W. Thomas, "Small is big in ICT: The impact of R\&D on productivity,” Telecomm. Policy, vol. 44, no. $1,2020$.

[32] Q. Zhou, P. Gao, and A. Chimhowu, "ICTs in the transformation of rural enterprises in China: A multi-layer perspective,” Technol. Forecast. Soc. Change, vol. 145, no. June 2018, pp. 12-23, 2019.

[33] A. Habibi, F. D. Yusop, and R. A. Razak, "The dataset for validation of factors affecting pre-service teachers' use of ICT during teaching practices: Indonesian context,” Data Br., vol. 28, 2020.

[34] J. M. Fernáández Batanero, M. M. Reyes Rebollo, and M. Montenegro Rueda, "Impact of ICT on students with high abilities. Bibliographic review (2008-2018),” Comput. Educ., vol. 137, no. April, pp. 48-58, 2019.

[35] R. Scherer and F. Siddiq, "The relation between students' socioeconomic status and ICT literacy: Findings from a meta-analysis," Comput. Educ., vol. 138, no. 0317, pp. 13-32, 2019.

[36] I. O. Adam, "Examining E-Government development effects on corruption in Africa: The mediating effects of ICT development and institutional quality,” Technol. Soc., vol. 61, no. December 2019, p. 101245, 2020.

[37] ROI, "Return On Investment (ROI) - Investopedia," 2016. [Online]. Available:http://www.investopedia.com/terms/r/returnoninvestment.asp. [Accessed: 02-Nov-2015].

[38] C. Gliedman, "The Foundation of Sound Technology Investment: The Total Economic Impact TM Methodology,” 2003.

[39] VMM, “The Value Measuring Methodology,” 2002.

[40] A. C. G. Maçada and M. M. Beltrame, "IT business value model for information intensive organizations,” BAR-Brazilian ..., pp. 44-65, 2012.

[41] R. Mirani and A. Lederer, "An instrument for assessing the organizational benefits of IS projects,” Decis. Sci., vol. 29, no. 4, pp. 803-838, 1998.

[42] M. Saunders, P. Lewis, and A. Thornhill, Research methods for business students, 5th ed. Financial Times Prentice Hall, 2011.

[43] R. Yin, Case study research: Design and methods, 5th ed. SAGE Publications, 2013.

[44] K. F. Punch, Introduction to Social Research: Quantitative and Qualitative Approaches, Third. SAGE Publications, 2013.

[45] J. Torrent-Sellens, P. Ficapal-Cusí, J. Boada-Grau, and A. Vigil-Colet, "Information and communication technology, co-innovation, and perceived productivity in tourism small and medium enterprises: an exploratory analysis,” Curr. Issues Tour., no. ahead-of-print, pp. 1-14, 2015.

[46] J. Manuel and C. Pérez, "Assessing the impact of Information and Communication Technologies on the Portuguese hotel sector: an exploratory analysis with Data Envelopment Analysis,” Tour. Manag. Stud., vol. 11, no. 1, pp. 35-43, 2015.

[47] N. M. Ongaki and F. W. Musa, "A Framework for Evaluating Ict Use in Teacher Education in Kenya,” Int. J. Res., vol. 2, no. 4, pp. 65-95, 2015.

[48] AGIMO, "Demand and Value Assessment Methodology," Canberra, Australia, 2004.

[49] A. Rai, R. Patnayakuni, and N. Patnayakuni, "Refocusing where and how IT value is realized: An empirical investigation,” Omega, vol. 24, no. 4, pp. 399-412, 1996.

[50] T. Winston, "Introduction to Case Study The Qualitative Report," vol. 3, no. 2, pp. 1-11, 1997.

[51] R. E. Stake, Multiple Case Study Analysis. Guilford Press, 2013.

[52] K. Eisenhardt, "Better stories and better constructs: The case for rigor and comparative logic,” Acad. Manag. Rev., vol. 16, no. 3, pp. 620-627, 1991.

[53] J. Hair, W. Black, B. Babin, R. Anderson, and R. Tatham, Multivariate data analysis, 7th ed. Upper Saddle River, NJ: Pearson Prentice Hall, 2010.

[54] H. W. Chou, H. H. Chang, Y. H. Lin, and S. Bin Chou, "Drivers and effects of post-implementation learning on ERP usage," Comput. Human Behav., vol. 35, pp. 267-277, 2014. 
[55] G. Westerman, "IT Risk Management: From IT Necessity to Strategic Business Value,” Massachusetts Inst. Technol., p. 15, 2006.

[56] E. Khakasa, "Evaluating Information Technology Investments - A Survey of Kenyan Commercial Banks,” Proc. 10th Annu. Conf. IAABD, no. 1992, pp. 473-480, 2009.

[57] A. S. A.-M. Al-Ghamdi and F. Saleem, "General characteristics and common practices for ICT projects: Evaluation perspective,” Int. J. Adv. Comput. Sci. Appl., vol. 9, no. 1, 2018.
[58] B. Ranti, "A Review of Information Technology Investment Evaluation Methodologies: The Need for Appropriate Evaluation Methods," Pros. Konf. Nas. Teknol. Inf. Komun. untuk Indones., no. 4, pp. 112-115, 2006.

[59] S. Shang and P. B. Seddon, "A comprehensive framework for classifying the benefits of ERP systems," AMCIS 2000 Proc., p. 39, 2000. 